\title{
Anoxia in Mice: Reduced Glucose in Brain with Normal or Elevated Glucose in Plasma and Increased Survival after Glucose Treatment
}

\author{
Jean Holowagh-Thurston, ${ }^{[17]}$ Righard E. Hauhart, and Elizabeth M. Jones \\ Edward Mallinckrodt Department of Pediatrics; Division of Neurology, St. Louis Children's Hospital; \\ Washington University School of Medicine, St. Louis, Missouri, USA
}

\begin{abstract}
Extract
Survival after 5 min of anoxia in 39 controls (8-12-day-old mice) was only 5\% compared with $82 \%$ in 39 glucose-treated littermates. Even after decapitation there was a delay in the onset of terminal gasping in the isolated heads of glucose-treated animals $(P=0.03)$ and the last gasp occurred much later than in the heads of control animals $(P<0.001)$. To study the mechanism of this phenomenon mice were injected with 30 $\mathrm{mmol} / \mathrm{kg}$ glucose subcutaneously. Control animals were given equiosmolal amounts of $\mathrm{NaCl}$. One hour later the animals were exposed to nitrogen gas $\left(\mathrm{O}_{2}\right.$ pressure $<5 \mathrm{~mm}$ $\mathrm{Hg})$. In glucose-treated mice the initial glucose concentration in brain was 3 times the control value $(P<0.001)$. ATP, P-creatine, and glycogen levels were unchanged. Although the rate of use of these compounds during anoxia was similar in both groups of mice, the high level of glucose in brain in glucose-treated mice permitted considerable sparing of these energy-yielding metabolites. In terms of actual and potential molar equivalents of high energy phosphate $(\sim \mathrm{P})$, the brain energy reserve after 4 min of anoxia in glucose-treated animals was twice that of controls, $10.70 \pm 0.72$ versus $4.75 \pm 1.19 \mathrm{mmol} / \mathrm{kg}(P=0.009)$.
\end{abstract}

\section{Speculation}

During acute anoxia, concentration of glucose in brains of young animals is critically reduced, although levels of glucose in plasma remain normal or may even become elevated. Pretreatment or concurrent administration of glucose increases anoxic survival. Because glucose has this dramatic life-saving effect in anoxic animals, the possibility that inadequate brain glucose supplies may occur in anoxic man in the face of normal or elevated levels of glucose in plasma should be considered.

\section{Introduction}

In experimental animals ischemic anoxia (decapitation) is associated with a striking decrease in brain glucose concentration $[7,10]$. The rate of cerebral glucose utilization during anoxia varies directly with age. During $30 \mathrm{sec}$ of ischemia in adult and 10-day-old mice, glucose in brain fell $80 \%$ and $60 \%$, respectively [10], whereas in newborn mice in twice this time the decrease was only $30 \%$ [7]. It is most interesting that in vivo a serious reduction of glucose in brain is not necessarily associated with a corresponding reduction in concentration of glucose in plasma. We have found this 
to be the case previously in acute experimental salicylate poisoning [8]. Oxygen deprivation is another example of this unexpected paradox. During $6 \mathrm{~min}$ of anoxia at $37^{\circ}$, glucose in brain in intact newborn mice fell $72 \%$, whereas, in the same interval, glucose concentration in plasma doubled [6]. In 10-day-old animals, levels of glucose in brain were nearly zero after 2 min of anoxia at $24^{\circ}$, and yet no changes in glucose concentration in plasma were seen even after $4 \mathrm{~min}$ (see Results).

When levels of glucose in blood are reduced, it is essential to administer glucose to restore and maintain normal brain function. However, in acute anoxia, levels of glucose in blood are not reduced. This raises the question of whether increasing the concentration of glucose in blood further might have a beneficial effect in anoxia. The answer is not immediately apparent since a continued supply of glucose for anaerobic glycolysis could conceivably increase lactic acid concentration to deleterious levels. However, there is some evidence that under these circumstances the administration of glucose can be life-saving. In 1942, Himwich and his associates [5] reported that the intraperitoneal injection of an unspecified amount of glucose doubled the survival time of 8-day-old rats in an atmosphere of nitrogen. Others have shown prolongation after decapitation of the persistence time of gasping of the isolated heads of rats receiving glucose injections [9]. Because anoxia is a common and potentially very serious complication in clinical medicine, it seemed important to us to extend these observations and to seek an explanation. Today modern techniques of rapid freezing of brain tissue to preserve labile metabolites and microanalytic methods of great sensitivity and specificity permit a biochemical approach to this problem.

\section{Methods}

\section{Preparation of Animals}

Before glucose treatment and biochemical investigation, the resistance to $\mathrm{O}_{2}$ deprivation in terms of survival was tested in 69 normal white mice ranging in age from a few hours to adulthood. Anoxia was produced by exposure of the animals to an atmosphere of nitrogen gas $\left(\mathrm{N}_{2}\right)$ at $37^{\circ}$ or at room temperature $(20$ $\left.24^{\circ}\right)$. The pressure of oxygen was monitored throughout the procedure with a Beckman oxygen electrode and was less than $5 \mathrm{~mm} \mathrm{Hg}$. Whereas none of the adult animals survived even $30 \mathrm{sec}$ of anoxia at $37^{\circ}$, newborn mice from birth to 37 hours of age could tolerate at least 20-30 min of $\mathrm{N}_{2}$ exposure at this temperature. By 10 days of age most of this tolerance had disappeared; at $37^{\circ}$ the limit of exposure to $\mathrm{N}_{2}$ compatible with life was only $1 \mathrm{~min}$, at room temperature it was 3-4 min. The extraordinary tolerance of the newborn to anoxia, the biochemical correlates in the brain, and a brief review of the pertinent literature have been presented previously [7].

To determine the effect of glucose on anoxic survival and anaerobic cerebral metabolism, 22 litters of white mice from birth to 12 days of age were used (over 200 animals). Animals of this age were selected because of our clinical interest in anoxia of newborn and young infants. One-half of each litter received $30 \mathrm{mmol} / \mathrm{kg}$ glucose in a volume of $30 \mathrm{ml}\left(\mathrm{H}_{2} \mathrm{O}\right) / \mathrm{kg}$ by subcutaneous injection; control littermates received an equal volume of equiosmolal $\mathrm{NaCl}(0.5 \mathrm{M})$. The effect of mannitol was also tested. Mannitol dosage was equal to that of glucose. Anoxia was produced as described above. With the exception of the newborn mice, only one control and one glucose-injected mouse (carefully paired for weight) were observed at a time. When mannitol was used, a saline solution control, a glucosetreated, and a mannitol-injected mouse were observed together.

For the investigation of the effect of glucose on anaerobic cerebral metabolism, animals were killed by quick freezing in liquid nitrogen at zero time and at the desired intervals of anoxia. When blood was needed, animals were killed by decapitation and blood collected from severed neck vessels in chilled heparinized capillary tubes.

\section{Preparation of Blood and Tissue Extracts and Methods of Assay for Metabolites}

Before dissection, all tissues were kept at $-80^{\circ}$. The brains of the frozen animals were dissected with sharp chisels in a cryostat at $-35^{\circ}$ and tissue samples were powdered and weighed in a cold room at $-23^{\circ}$. Tissue extracts were prepared according to the procedure of Lowry et al. [10] and were stored at $-80^{\circ}$ until the time of assay.

All metabolites were measured fluorometrically by specific enzymic methods. ATP, P-creatine, and glucose were assayed by the methods of Lowry et al. [10]. Lactate and glycogen were measured by the methods of Gatfield et al. [4]. For the determination of concentrations of glucose in the blood, samples of heparinized plasma were diluted $10-20$ times in $0.5 \mathrm{~m}$ perchloric acid and centrifuged at $4^{\circ}$. The supernatant fluid was 
removed and stored at $-80^{\circ}$ until the time of assay. The addition of aliquots of the perchloric acid extracts in the volume required for assay did not produce a change in the $\mathrm{pH}$ of the reagent buffer or affect the complete recovery of standards. Therefore, no preliminary neutralization of the extracts was made.

\section{Calculation of Cerebral Energy Reserve as High Energy Phosphate $(\sim P)$}

We followed the example of Lowry et al. [10], in that actual and potential molar equivalents of $\sim \mathrm{P}$ were calculated as 1 eq $\sim \mathrm{P} / \mathrm{mol}$ P-creatine, $2 /$ mol ATP and glucose, and 2.9 eq for each glucose equivalent of glycogen.

\section{Comment on Clinical Aspects}

The clinical behavior of mice after exposure to nitrogen gas is relevant to this study. During the first few seconds of anoxia, 8-12-day-old animals struggle violently, they void, a few jerks are seen, and then the mice are perfectly still-little or no breathing is apparent until the onset of terminal gasping. Death is imminent shortly after this time if the animals are not removed from nitrogen. Resuscitation is not possible after the last gasp in nitrogen.

The behavior of the head after decapitation is also characteristic. During the first $15 \mathrm{sec}$ or so there is fairly rapid but shallow gasping of the isolated head and then it, too, is still till the onset of terminal gasping.

\section{Results}

\section{Effect of Glucose on Anoxic Survival}

The effect of glucose on increasing survival of anoxic 8-12-day-old mice was truly dramatic (Table I). In fact, in only one of the seven litters used for this table were there any survivals among control animals. It was also observed that in all glucose-treated mice there was a delay in the onset of terminal gasping (Table I). Even after decapitation there was a significant delay in the onset of terminal gasping in glucose-treated animals, and, as in the case of the intact animal, the last gasp occurred much later (Table II). The number of gasps in controls was consistently at least twice that seen in glucose-treated animals. A similar reduction in the frequency of terminal gasps in glucose-treated mice was observed in vivo during anoxia. The explanation of this curious finding is unknown.
Table 1 . Effect of glucose pretreatment on anoxic mice ${ }^{1}$

\begin{tabular}{|c|c|c|}
\hline \multirow{2}{*}{ Clinical observation } & \multicolumn{2}{|c|}{$8-12$-Day-old mice } \\
\hline & Control & Glucose treated \\
\hline $\begin{array}{l}\text { Survival after } 4.9 \pm 0.2^{2} \mathrm{~min} \\
\text { anoxia at } 20-24^{\circ}, \%\end{array}$ & $5(39)$ & $82(39)$ \\
\hline $\begin{array}{l}\text { Time to onset of terminal } \\
\text { gasping, min }\end{array}$ & $3.8 \pm 0.4^{2}(7)^{3}$ & $\begin{array}{r}5.0(1)^{3} \\
6.5(1) \\
>7.0(5)\end{array}$ \\
\hline
\end{tabular}

${ }^{1}$ Seven litters of 8-12-day-old mice were used in this study. The number of animals is given in parentheses. Animals were exposed to $\mathrm{N}_{2}$ gas (see Methods) 15-104 min after injection of glucose or saline solution $(60.7 \pm 4.1 \mathrm{~min}$ (mean $\pm \mathrm{SE}$ ). The interval of anoxia ranged from 3 to $7 \mathrm{~min}$.

${ }^{2}$ Mean $\pm \mathrm{se}$.

${ }^{3}$ Experiment concluded after 7 min of anoxia. All controls were dead; all glucose animals alive. Five of the seven glucose-treated animals had not begun terminal gasping after $7 \mathrm{~min}$ of anoxia.

Table II. Effect of glucose pretreatment on gasping of isolated head of 10-day-old mice ${ }^{1}$

\begin{tabular}{|c|c|c|c|}
\hline $\begin{array}{c}\text { Clinical } \\
\text { observation }\end{array}$ & $\begin{array}{l}\text { Control } \\
\text { (7), } \min \end{array}$ & $\begin{array}{l}\text { Glucose treated } \\
\text { (11), min }\end{array}$ & $P$ value \\
\hline \multicolumn{4}{|l|}{$\begin{array}{l}\text { Onset of terminal } \\
\text { gasping }\end{array}$} \\
\hline Range & $1.33-3.33$ & $2.66-5.50$ & \multirow{2}{*}{0.03} \\
\hline Mean \pm SE & $2.45 \pm 0.28$ & $3.50 \pm 0.27$ & \\
\hline \multicolumn{4}{|l|}{ Time of last gasp } \\
\hline Range & $1.80-5.58$ & $5.42-8.03$ & \multirow{3}{*}{$<0.001$} \\
\hline Mean $\pm \mathrm{sE}$ & $4.17 \pm 0.53$ & $6.72 \pm 0.28$ & \\
\hline $\begin{array}{l}\text { No. gasps in last } \\
\text { minute }\end{array}$ & & & \\
\hline $\begin{array}{l}\text { Range } \\
\quad \text { (gasps/min) }\end{array}$ & $5-12$ & $1-7$ & \multirow{2}{*}{$<0.001$} \\
\hline Mean $\pm \mathrm{SE}$ & $7.8 \pm 0.9$ & $3.3 \pm 0.5$ & \\
\hline
\end{tabular}

1 Two litters of 10-day-old mice were used. The number of animals is given in parentheses. Mice were killed by decapitation $1 \mathrm{hr}$ after glucose or saline solution injection (see Methods). The isolated head was observed at $24^{\circ}$.

In newborn mice the effect of glucose on the resistance to anoxia is also impressive, particularly at the higher environmental temperature (Table III). At $34^{\circ}$ only 1 control mouse out of 11 survived $25 \mathrm{~min}$ of anoxia, compared with survival of all 11 glucose-treated littermates.

In both age groups there was no difference in the survival rates between normal mice (not injected) and littermates injected with hypertonic saline solution. No effect was seen with mannitol. None of 11 mannitol or 10 saline solution-injected, 10-day-old mice survived $4.38 \pm 0.35 \mathrm{~min}$ of anoxia compared with a $55 \%$ survival in 11 glucose-treated littermates. 
Effect of Glucose on Brain Energy Metabolism during Anoxia

The life-saving effect of glucose in anoxic mice does not appear to be related to its osmotic activity, inasmuch as mannitol in equal dosage was without effect. In an attempt to understand the mechanism of the protective action of glucose during anoxia, the effects of glucose administration on the major components of the energy reserve of the brains of 10-day-old mice and on the use of these metabolites during anoxia $\left(24^{\circ}\right)$ compared with controls were studied (Fig. 1, $A$ and $B$ ). Although the initial level of glucose in the brains of glucose-injected mice was 3 times the control level

Table III. Effect of glucose pretreatment on anoxic mice ${ }^{1}$

\begin{tabular}{lrr}
\hline \multirow{2}{*}{ Clinical observation } & \multicolumn{2}{c}{ Neonate } \\
\cline { 2 - 3 } & Control & Glucose treated \\
\hline Survival after $39.2 \pm 1.1^{2}$ min at $24^{\circ}, \%$ & $40(10)$ & $100(11)$ \\
Survival after $25 \mathrm{~min}$, at $34^{\circ}, \%$ & $9(11)$ & $100(10)$ \\
Total, $\%$ & $24(21)$ & $100(21)$
\end{tabular}

${ }^{1}$ Four litters of newborn mice (24-36 hr) were used in this study. The number of animals is given in parentheses. The mice were exposed to $\mathrm{N}_{2}$ gas immediately after injection (see Methods). The interval of anoxia ranged from $25-43 \mathrm{~min}$.

${ }^{2}$ Mean $\pm \mathrm{SE}$.

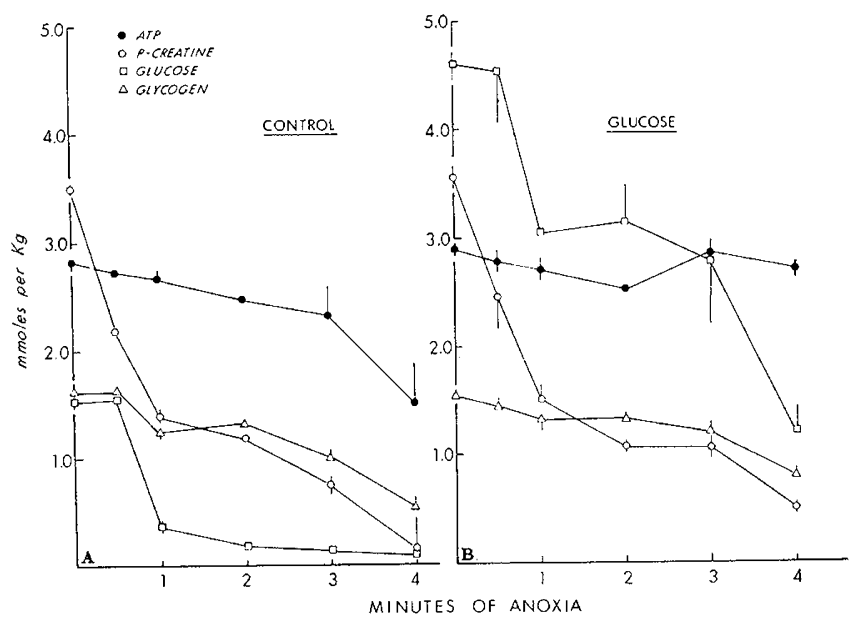

Fig. 1. A: Concentrations of P-creatine, ATP, glucose, and glycogen in the brains of 10 -day-old mice injected $1 \mathrm{hr}$ previously with $0.5 \mathrm{M} \mathrm{NaCl}(15 \mathrm{mmol} / \mathrm{kg}$ subcutaneously). Brain tissues was sampled at zero time and at intervals after anoxia $\left(24^{\circ}\right)$. Each point is the mean of values for $2-4$ mice, a total of 22 animals. In $A$ and $B$ vertical lines represent \pm 1 SE $(3-4$ samples $) . B$ : This is similar to $A$ except that the mice (littermates of the animals in A) received $30 \mathrm{mmol} / \mathrm{kg}$ of glucose subcutaneously. Each point is the mean of values from $2-4$ mice, a total of 20 animals. One glucose ralue at $1 \mathrm{~min}, 1.67 \mathrm{mmol} / \mathrm{kg}$, was not included.

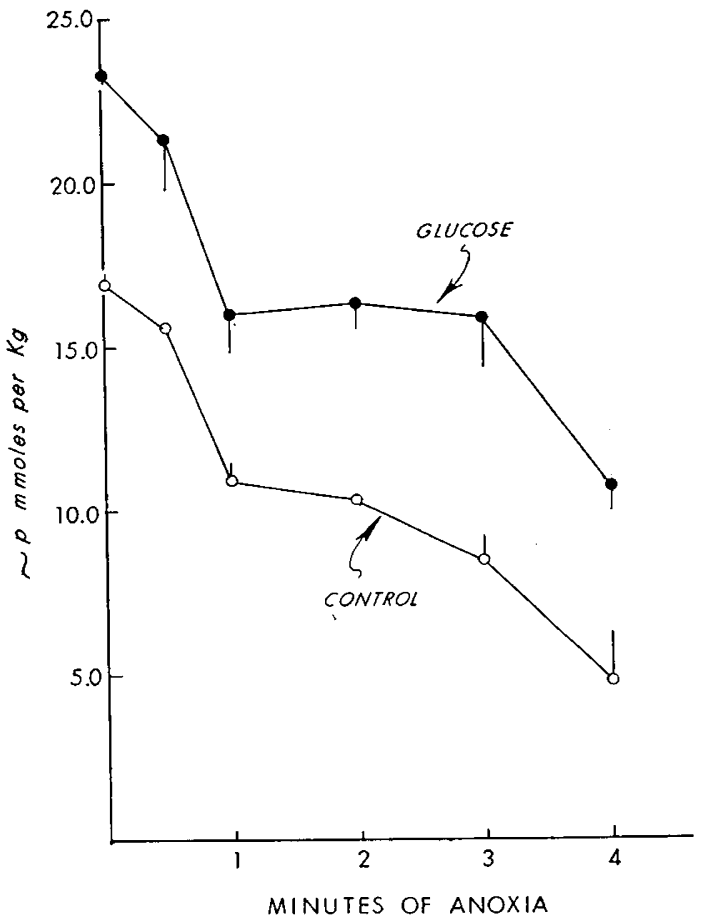

Fig. 2. High energy phosphate $(\sim \mathrm{P})$ as a function of time during anoxia. High energy phosphate was calculated as described in Methods. The points represent the same number of animals as in Fig. $1, A$ and $B$. Values are given as the mean $\pm 1 \mathrm{SE}$ (vertical lines).

$(P<0.001)$ values for ATP, $\mathrm{P}$-creatine, and glycogen were almost identical in the two groups of animals. Calculating these metabolites in terms of actual and potential molar equivalents of $\sim \mathrm{P}$ (see Methods) the value for glucose-treated mice was $36 \%$ greater than in controls, $P<0.001$.

The high level of glucose in brain in experimental animals had no effect on the rate of energy use during anoxia (Fig. 2). The total decrease in $\sim \mathrm{P}$ equivalents during the 4-min interval of anoxia was equal in control and glucose-treated mice, 12.16 and $12.33 \mathrm{mmol} / \mathrm{kg}$, respectively. The rate of fall was also similar in the two groups of animals. However, the continuing supply of glucose for energy use during anoxia in the glucosetreated animals permitted considerable sparing of the energy-yielding metabolites. To fully appreciate the striking differences between controls and glucosetreated mice, residual levels of these metabolites after 4 min of anoxia are shown in Table IV. In terms of $\sim \mathrm{P}$ the brain energy reserve in glucose-treated mice was now twice as high as in the controls $(P=0.009)$.

Initial brain lactate values in control and glucosetreated mice were not significantly different, $1.00 \pm$ 
Table $I V$. Effect of $4 \mathrm{~min}$ of anoxia on brain energy reserves ${ }^{1}$

\begin{tabular}{lccl}
\hline Metabolite & $\begin{array}{c}\text { Control (4), } \\
\mathrm{mmol} / \mathrm{kg}\end{array}$ & $\begin{array}{c}\text { Glucose injected } \\
(4), \mathrm{mmol} / \mathrm{kg}\end{array}$ & $P$ value \\
\hline P-creatine & $0.15 \pm 0.14$ & $0.50 \pm 0.05$ & 0.09 \\
ATP & $1.48 \pm 0.39$ & $2.71 \pm 0.07$ & 0.04 \\
Glucose & $0.07 \pm 0.01$ & $1.21 \pm 0.22$ & 0.005 \\
Glycogen & $0.52 \pm 0.09$ & $0.80 \pm 0.03$ & 0.05 \\
\hline
\end{tabular}

1 The data are from the mice used for Fig. $1, A$ and $B$. The number of animals is given in parentheses. Values are means $\pm \mathrm{SE}$.

0.16 and $1.39 \pm 0.22 \mathrm{mmol} / \mathrm{kg}$, respectively. Final brain lactate values were $6.68 \pm 0.4 \mathrm{mmol} / \mathrm{kg}$ in controls and $9.37 \pm 0.52$ in glucose-treated animals $(P<0.001)$. In both groups of animals the increment in lactate during the 4-min interval of anoxia was very near the expected value calculated from the decreases in glucose and glycogen.

In 19 other mice of this age, there was no change in glucose in plasma during an equal interval of anoxia ( $5.48 \pm 0.41 \mathrm{~mm}$ at zero time ( 6 mice), $5.65 \pm 0.14 \mathrm{~mm}$ at $2 \mathrm{~min}$ ( $6 \mathrm{mice})$, and $4.90 \pm 0.29 \mathrm{mM}$ at $4 \mathrm{~min}(7$ mice)).

Pertinent to this study is the rate and the degree of increase in brain glucose concentration after glucose administration in normal animals (Fig. 3). At all ages from 1 to 22 days there were significant increases in brain glucose levels $5 \mathrm{~min}$ after injection by either route of administration (intraperitoneal or subcutaneous) and at $10 \mathrm{~min}$ the levels were at least double the zero time values. These findings in brain are paralleled by similar changes in plasma glucose in these same animals. At $5 \mathrm{~min}$ the level was $20.1 \pm 3.1 \mathrm{~mm}$ in the newborn animals and $26.0 \pm 1.7 \mathrm{~mm}$ in the 22-dayold animals. At $10 \mathrm{~min}$, values were $28.1 \pm 3.4 \mathrm{~mm}$ and $30.8 \pm 4.0 \mathrm{~mm}$, respectively.

\section{Discussion}

When the blood circulation to the brain is interrupted (decapitation) in mice of all ages there is a striking increase in the rate of glucose utilization by the ischemic brain $[7,10]$. Similar changes occur in the brains of intact newborn [6] and 10-day-old mice during anoxia and in those of adult mice [3]. The mechanism of the increase in glycolysis in anoxic brain, the so-called "Pasteur effect," is now well understood $[1,2,11-13]$. The profound reduction of brain glucose concentration during acute anoxia in young mice is not reflected in, nor a reflection of, reduced levels of glucose in the blood. In fact, in newborn mice, concentration of glucose in plasma doubled while glucose in brain fell $72 \%$. In 10-day-old mice, levels of plasma in glucose were unchanged over a 4-min interval of anoxia. Because the experiments in the newborn mice were performed at $37^{\circ}$ and the 10-day-old mice were studied at room temperature, no age comparisons can be made. We have studied the mechanism of the paradox of reduced glucose in brain despite elevated concentration of glucose in plasma during anoxia in newborn mice [6]. In the neonate the increase in lactate in brain during 6 min of anoxia was more than twice that expected from the combined decreases in concentration of glucose and glycogen in brain. These findings are compatible with an increased glucose influx from the blood to the brain during anoxia. Apparently, levels of glucose in brain fell because the increase in cerebral anaerobic glycolysis was greater than the increase in glucose transport. However, in the 10-day-old animals the decreases in glucose and glycogen and the increase in lactate were very nearly in balance. Therefore, either there was no effective transfer of glucose from blood to brain, or, as seems more likely, lactate removal by the circulating blood kept pace with glucose uptake. Whether an increase in glucose uptake occurred during anoxia cannot be determined.

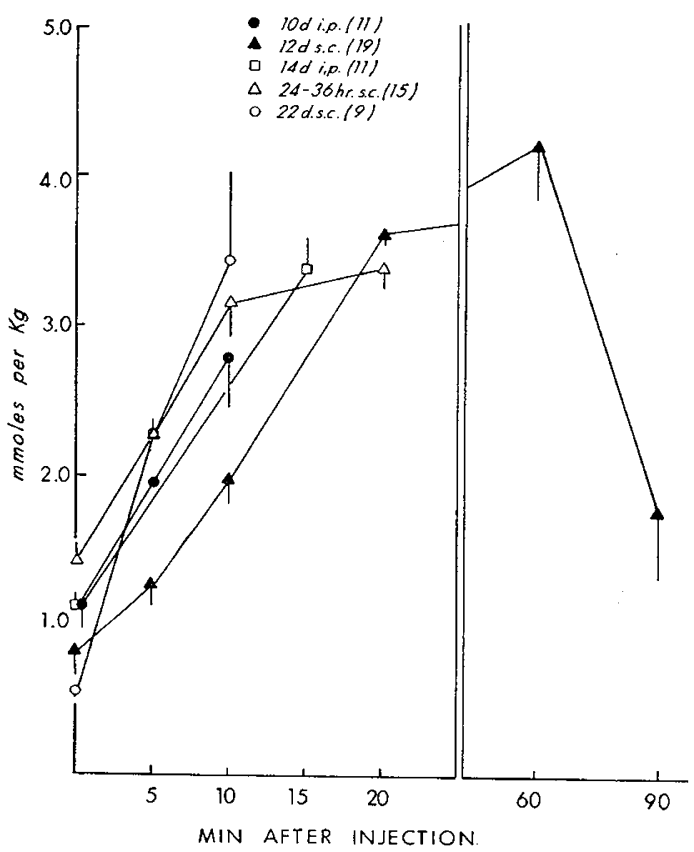

Fig. 3. Levels of glucose in the brain of normal mice at intervals after injection of glucose or saline solution (see Methods). The route of administration was subcutaneous (s.c.) or intraperitoneal (i.p.). The number of mice is given in parentheses. Each value is the mean of 2-6 animals. The vertical lines represent \pm 1 SE (three or more samples). Values for controls did not differ with time, therefore results were pooled and shown at zero time. 
It is possible that these observations in animals have important clinical implications. In human beings, measurements of the concentration of glucose in the blood are often used to exclude hypoglycemia as a cause of abnormal neurologic signs and symptoms. However, from the present experiments and those reported previously [6], it appears that normal or even elevated glucose levels in the blood cannot be assumed to indicate adequate amounts of glucose in the brain.

Although the beneficial effects of glucose pretreatment in mice exposed to anoxia are unequivocal, neither the clinical nor the biochemical data permit a distinction between the relative roles of the cardiovascular system and the increased cerebral energy reserve in increasing survival. However, the findings in the isolated head (delayed onset of terminal gasping and prolongation of the time to the last gasp, which signals death in the intact animal) after glucose administration suggest that glucose administration plays an important role in prolonging the survival of the brain, as Himwich et al. [5] found, and that it does this by increasing the available energy reserves.

\section{Summary}

Previous studies of the effect of anoxia in young animals have revealed that the content of glucose in brain can be reduced critically despite normal or even elevated concentration of glucose in plasma. The present report is a study of the effects of glucose injection on survival and on the components of the brain energy reserve during anoxia. The data show that glucose has a dramatic effect on increasing anoxic survival. Biochemical correlates in brain suggest that a mechanism of this action is an increase in the available energy reserves.

\section{References and Notes}

1. Arsenberc, A. C.: Sugar phosphate levels in the mitochondrial Pasteur effect. J. Biol. Chem., 234: 44I (1959).

2. Aisenberg, A. C., Reinfarge, B., And Potter, V. R.: Studies on the Pasteur effect. I. General Observations. J. Biol. Chem., 224: 1099 (1957).

3. Duffy, J. E., Nelson, S. R., And Lowry, O. H.: Cerebral car- bohydrate metabolism during acute hypoxia and recovery. J. Neurochem., 19: 959 (1972).

4. Gatfield, P. D., Lowry, O. H., Schulz, D. W., and PasSONNEAU, J. V.: Regional energy reserves in mouse brain and changes with ischaemia and anesthesia. J. Neurochem., 13: 185 (1966).

5. Himwich, H. E., Bernstein, A. O., Herrlich, H., Chesler, A., AND FazeKas, J. F.: Mechanisms for the maintenance of life in the newborn during anoxia. Amer. J. Physiol., 135: 387 (1942).

6. Holowach-Thurston, J., Hauhart, R. E., Jones, E. M., Ikossi, M. G., AND PIERCE, R. W.: Decrease in brain glucose in anoxia in spite of elevated plasma glucose levels. Pediat. Res., $7: 691$ 1973.

7. Holowach-Thurston, J., McDougal, Jr., D. B.: Effect of ischemia in metabolism of the brain of the newborn mouse. Amer. J. Physiol., 216: 348 (1969).

8. Holowach-Thurston, J., Pollock, P. G., Warren, S. K., JONES, E. M.: Reduced brain glucose with normal plasma glucose in salicylate poisoning. J. Clin. Invest., 49: 2139 (1970).

9. Jilek, L., Fischer, J., Krulich, L., and Trojan, S.: Progress in Brain Research, Vol. 9, p. 113, The Developing Brain. (Elsevier Publishing Co., Amsterdam, 1964).

10. Lowry, O. H., Passonneau, J. V., Hasselberger, F. X., Schulz, D. W.: Effect of ischemia on known substrates and cofactors of the glycolytic pathway in brain. J. Biol. Chem., 239: 18 (1964).

11. Passonnead, J. V., And Lowry, O. H.: Phosphofructokinase and the Pasteur effect. Biochem. Biophys. Res. Commun., 7: 10 (1962).

12. Thorn, W., Pflemerer, G. P., Frowein, R. A., And Ross, I.: Stoffwechselvorgange im gehirn bei akuter anoxie, akuter ischamie und in der erholung. Pflugers Archiv., 261: 334 (1955).

13. Thorn, W., Scholl, H., Pfleiderer, G., and Mueldener, B.: Metabolic processes in the brain at normal and reduced temperatures and under anoxic and ischaemic conditions. J. Neurochem., 2: 150 (1958).

14. We thank Dr. David McDougal, Jr., for his many helpful suggestions and review of this manuscript.

15. Presented in part at the Fourth Meeting of the American Society for Neurochemistry, Columbus, Ohio, March 13, 1973.

16. This investigation was supported in part by United States Public Health Grant no. NB 06163 and the Allen P. and Josephine B. Green Foundation, Mexico, Mo.

17. Requests for reprints should be addressed to: J. HolowachThunston, M.D., Department of Pediatrics, St. Louis Children's Hospital, 500 South Kingshighway, St. Louis, Mo. 63110 (USA).

18. Accepted for publication November 15, 1973. 